\title{
OPEN Author Correction: Plant recording across two centuries reveals dramatic changes in species diversity of a Mediterranean archipelago
}

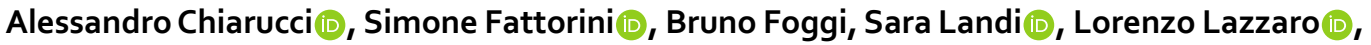 \\ János Podani \& Daniel Simberloff
}

Correction to: Scientific Reports https://doi.org/10.1038/s41598-017-05114-5, published online 14 July 2017

The Supplementary Table S1 file that accompanies this Article contains a typographical error in Table S1. The area value for 'Elba' incorrectly reads as '2244.09', this should read as '223.241'.

\begin{abstract}
(c) (i) Open Access This article is licensed under a Creative Commons Attribution 4.0 International C. License, which permits use, sharing, adaptation, distribution and reproduction in any medium or format, as long as you give appropriate credit to the original author(s) and the source, provide a link to the Creative Commons license, and indicate if changes were made. The images or other third party material in this article are included in the article's Creative Commons license, unless indicated otherwise in a credit line to the material. If material is not included in the article's Creative Commons license and your intended use is not permitted by statutory regulation or exceeds the permitted use, you will need to obtain permission directly from the copyright holder. To view a copy of this license, visit http://creativecommons.org/licenses/by/4.0/.
\end{abstract}

(C) The Author(s) 2019 